\title{
Snowball Earth ocean chemistry driven by extensive ridge volcanism during Rodinia breakup
}

\author{
T. M. Gernon ${ }^{a, *}$, T. K. Hincks ${ }^{b}$, T. Tyrrell ${ }^{a}$, E. J. Rohling ${ }^{a, c}$, M. R. Palmer $^{a}$ \\ ${ }^{a}$ Ocean and Earth Science, University of Southampton, European Way, Southampton SO14 3ZH, U.K. \\ ${ }^{\mathrm{b}}$ School of Earth Sciences, University of Bristol, Bristol, BS8 1RJ, U.K. \\ ${ }^{c}$ Research School of Earth Sciences, The Australian National University, Canberra, ACT. 2601, Australia
}

\begin{abstract}
During Neoproterozoic Snowball Earth glaciations, the oceans gained massive amounts of alkalinity, culminating in the deposition of massive cap carbonates upon deglaciation. Changes in terrestrial runoff associated with both breakup of the Rodinia supercontinent and deglaciation can explain some, but not all of the requisite changes in ocean chemistry. Submarine volcanism along shallow ridges formed during supercontinent breakup results in the formation of large volumes of glassy hyaloclastite, which readily alters to palagonite. Here we estimate fluxes of calcium, magnesium, phosphorus, silica and bicarbonate associated with these shallow ridge processes, and argue that extensive submarine volcanism during the breakup of Rodinia made an important contribution to changes in ocean chemistry during Snowball Earth glaciations. We use Monte Carlo simulations to show widespread hyaloclastite alteration under near-global sea ice cover could lead to $\mathrm{Ca}^{2+}$ and $\mathrm{Mg}^{2+}$ supersaturation over the course of the glaciation that is sufficient to explain the volume of cap carbonates deposited. Furthermore, our conservative estimates of phosphorus release are sufficient to explain the observed P:Fe ratios in sedimentary iron formations from this time. This large phosphorus release may have fuelled primary productivity, which in turn would have contributed to atmospheric $\mathrm{O}_{2}$ rises that followed Snowball Earth episodes.
\end{abstract}

\footnotetext{
* Corresponding author.

Email address: Thomas.Gernon@noc.soton.ac.uk (T. M. Gernon).
} 
Breakup of the Rodinia supercontinent contributed to profound environmental change during the Neoproterozoic $(\sim 1000-540 \mathrm{Ma})$. It is thought that ice-sheets reached the equator ${ }^{1,2}$ and global temperatures dropped to $-50^{\circ} \mathrm{C}$ during two long-lived 'snowball' events: the Sturtian (Cryogenian) glaciation at c. 720-660 Ma and the Marinoan (Varanger) glaciation at c. 650-630 Ma. These globally distributed glaciations have been attributed to major continental reconfiguration episodes ${ }^{3,4}$. Protracted rifting around c. $750^{3}-725 \mathrm{Ma}^{5}$ (lasting 100-120 Myr) formed the Proto-Pacific Ocean (Fig. 1a). The Sturtian glaciation coincided with initial breakup in Canada at c. $720 \mathrm{Ma}^{6}$, and the Marinoan with a later phase of the same breakup event in Antarctica from 670-650 $\mathrm{Ma}^{7}$. Another major breakup event between c. $615 \mathrm{Ma}^{8}$ and $550 \mathrm{Ma}^{9}$ formed the Iapetus Ocean (Fig. 1b), concurrent with the Gaskiers glaciation at c. 582-580 Ma.

It has been suggested that (a) continental breakup led to sharp increases in riverine runoff and silicate weathering (including flood basalts ${ }^{10}$ ), causing enhanced $\mathrm{CO}_{2}$ drawdown and descent into a 'snowball' state ${ }^{4}$; and (b) deglaciation resulted from gradual accumulation of atmospheric $\mathrm{CO}_{2}{ }^{11}$, likely from subaerial volcanic outgassing ${ }^{12}$, to critical levels capable of overcoming an ice albedo effect ${ }^{2}$. Intense debate centres on the source of alkalinity required to form the extensive cap carbonate sequences associated with Snowball Earth termination, and their negative $\delta^{13} \mathrm{C}$ signatures ${ }^{2,12,13}$. Carbonate sedimentation may have occurred rapidly $(<10 \mathrm{kyr})^{12}$ due to a post-glacial greenhouse weathering spike ${ }^{14,15}$ of similar duration to Quaternary deglaciation ${ }^{16}$. However, magnetopolarity reversals exhibited in some Marinoan cap carbonates suggest accumulation took place over longer timescales $(\geq 100 \mathrm{kyr})^{17,18}$. Similarly, meltback alone cannot easily explain the inferred increase in dissolved oceanic phosphate concentrations during the Tonian and Cryogenian periods ${ }^{19}$. Despite the temporal coincidence between breakup of Rodinia and glaciations $^{3,4}$, as yet no studies have investigated the direct impacts of volcanism associated with extensive spreading ridge formation (Supplementary Information (SI) Fig. 1).

\section{The shallow ridge hypothesis}

Here we propose the novel shallow ridge hypothesis, which invokes ridge volcanism to drive efficient and long-lived seafloor alteration, and in conjunction with other weathering processes linked to continental breakup ${ }^{4,10,20}$ can reconcile many key features of Snowball Earth episodes.

Continental unzipping of the type associated with the breakup of Rodinia is accompanied by enhanced rifting and magmatism, and can coincide with an order of magnitude increase in magmatic productivity ${ }^{21}$. The early phase 
of ocean crustal development involves a period of relatively shallow marine volcanism (Fig. 1c), as the ridge axis gradually subsides ${ }^{22}$. This low hydrostatic pressure regime favours explosive fragmentation of lava in contact with seawater ${ }^{23}$, yielding voluminous hyaloclastite - a pyroclastic rock dominated by juvenile angular glass fragments - along the newly formed ridge (Fig. 1d). Hyaloclastite volcanism in early rifting environments is a rapid, high-volume process, forming from volcanic centres $30-40 \mathrm{~km}$ wide, and producing mounds $\sim 1.5 \mathrm{~km}$ high and 15-20 km wide ${ }^{22}$. Observations and empirical subsidence relationships indicate that conditions favourable for hyaloclastite formation (depths up to $2 \mathrm{~km}$ ) would persist along the ridge for at least 20 Myr (SI Fig. 2).

The quenched glass shards typical of basaltic hyaloclastites are very susceptible to alteration, largely by hydration to palagonite ${ }^{24}$. This is enhanced by a high reactive surface area:volume ratio and high porosity (compared to pillow lavas) that greatly increases seawater interaction. Basaltic glass alteration involves considerable element mobilisation (e.g. Ca losses of $\sim 90 \%^{25}$ ), thus has the potential to exert a major control on seawater chemistry ${ }^{24}$, including consumption of aqueous $\mathrm{CO}_{2}{ }^{26}$. The shallow ridge is also a major source of magnesium, with basaltic glass experiencing $\mathrm{Mg}$ losses of $\sim 67 \%^{25}$ to $\sim 97 \%{ }^{24}$. Dissolution rates of basaltic glass could be reduced ${ }^{24}$ at the low temperatures expected in an ice-covered ocean, but our model purely evaluates the initial element flux during rapid quenching, followed by cation leaching ${ }^{24}$, and does not require total glass dissolution. As hyaloclastites accumulate in thick 'piles' along the ridge axis, they are susceptible to high temperature hydrothermal circulation leading to further losses through diffusion ${ }^{24}$ - conditions thought to persist for $\sim 10^{6} \mathrm{yr}^{27}$. Conservatively, we only consider contributions from freshly erupted material close to the ridge axis. Palagonitization of basaltic glass occurs rapidly at high temperatures ${ }^{24}$, and potentially within one year in hydrothermal systems ${ }^{28}$. Thus, hyaloclastite alteration can be considered almost instantaneous on geological timescales.

This global scale process offers an alternative, complementary explanation for the surge of alkalinity associated with the Neoproterozoic "calcium ocean" and carbonate sedimentation, which cannot be satisfactorily explained by terrestrial weathering alone ${ }^{29}$. The process can also help explain the late Neoproterozoic 'excess phosphate ocean' 19 and high concentrations of $\mathrm{SiO}_{2}$ in banded iron formations $(\mathrm{BIF})^{30}$. Although we focus on Rodinia, shallow ridge effects will have similarly large impacts on ocean fluxes during any major episode of continental breakup, albeit manifest in different ways due to variations in timescales and extent of magmatic productivity, alteration and biological productivity in the ocean. It is unclear why Pangea break-up did not result in global glaciation, although the more polar location of continents may have suppressed the continental silicate weathering $\mathrm{CO}_{2}$ sink. 


\section{Breakup of Rodinia}

The 750-725 Ma breakup involved at least $\sim 2 \times 10^{4} \mathrm{~km}$ spreading-ridge formation around the perimeter of Laurentia (Fig. 1a) ${ }^{3}$. Subsequent rift and drift episodes ${ }^{3,5}$ may have increased the total length of new spreading ridges by 3-4 times. Although Neoproterozoic ocean crust is poorly represented in the geological record (e.g. due to subduction), there is evidence for widespread hyaloclastite emplacement during breakup, prior to 'snowball' glaciations (Fig. 2). For example, the 717-716.5 Ma Mount Harper Volcanic Complex ${ }^{6}$ - a 1.6 $\mathrm{km}$ thick succession of subaqueous hyaloclastites, breccias and lavas emplaced along the rifted northwestern Laurentian margin ${ }^{31}$ - is directly overlain by Sturtian glacial diamictites. Rift-related volcanism would have continued during glaciations (SI Table 1), as newly formed ocean crust progressively unzipped to form the extensive Proto-Pacific ridge system. Crucially, and in contrast to most other biogeochemical fluxes, hyaloclastite-derived ocean fluxes will not have been affected by near-global ice cover.

There is also evidence for extensive volcanism, again associated with Rodinia breakup, prior to the Marinoan glaciation (e.g. 670-650 Ma in Antarctica $^{7}$; Fig. 2). The apparent 'delay' in initiation of rifting between Laurentia and Antarctica confirms that breakup was protracted ${ }^{3}$, and seafloor spreading continued throughout the Sturtian and Marinoan glaciations. Similarly, basaltic hyaloclastites associated with the early opening of Iapetus $(\sim 615-580 \mathrm{Ma})$ are recognised globally (Fig. 2; SI Table 1). Hyaloclastites are directly overlain by diamictites associated with the Gaskiers glaciation ${ }^{32}$, signifying explosive shallow marine volcanism before (and likely during) the Gaskiers event (Fig. 2).

Better time constraints in the Neoproterozoic are needed to explore whether shallow ridge volcanism could have played a key role in initiating snowball glaciation. However, this is feasible given: (1) an intrinsic need for continental breakup in order to intensify silicate weathering ${ }^{4,10}$, and (2) isotopic evidence for copious weathering of juvenile mantle-derived volcanics before the Sturtian glaciation $^{33}$.

\section{Hyaloclastite alteration fluxes into the ocean}

We develop Monte Carlo simulations to quantify potential chemical fluxes (Ca, $\mathrm{P}, \mathrm{Si}, \mathrm{Mg}$ ) into the ocean during shallow ridge volcanism. Given the significant uncertainties in initial conditions and fluxes (e.g. seawater chemistry, pH), this situation does not lend itself to deterministic modelling, but instead must be probabilistically assessed. Here, we present a parsimonious model, supported 
by observations and experiments (Table 1 , methods), broadly capturing the key processes and associated uncertainties. Ridge length is varied from 0.5 to 2 $\times 10^{4} \mathrm{~km}$ to simulate progressive separation of Laurentia ${ }^{3}$, and full spreading rates from 50 to $200 \mathrm{~mm} \mathrm{yr}^{-1}$ to represent moderate ${ }^{34}$ to fast $^{35}$ rates expected during breakup ${ }^{5}$. The simulations account for secondary mineral formation, for example carbonate fluorapatite (CFA) formation following release of $\mathrm{P}_{2} \mathrm{O}_{5}$ during glass alteration, and smectite (saponite) formation as a sink for silica. Fluxes calculated here exclude background seafloor weathering and hydrothermal processes ${ }^{36}$ associated with contemporary deep ridge systems, e.g. in the Mirovia superocean (Fig. 1a), which would increase Ca, P, Si and Mg oceanic input.

Hyaloclastite formation rates (and hence magnitude of the chemical fluxes) vary spatially and temporally during ridge formation, hence our deliberately wide and conservative parameter ranges (Table 1). All input distributions are sampled independently because of insufficient observational evidence to accurately define correlations, but three more tightly constrained scenarios (SI Table 2) explore sensitivity of the calculated fluxes to independence assumptions. The high hyaloclastite production scenario (I, SI Table 2) involves both rapid and spatially extensive unzipping. A further simulation explores the potential correlation between ridge length and magmatic productivity, arising from the temporal evolution of the ridge system.

Given $\mathrm{CaO}$ losses from hyaloclastites range from $4-10 \mathrm{wt} \%^{24,25}$, our simulations suggest optimal spreading conditions along the length of the ProtoPacific ridge could yield a maximum Ca flux of $1.4 \times 10^{13} \mathrm{~mol} \mathrm{yr}^{-1}$ (Fig. 3a; SI Fig. 3a); comparable to the modern dissolved riverine flux of $\sim 1.2 \times 10^{13}$ mol $\mathrm{yr}^{-1}$ (ref. ${ }^{37}$ ) and 1-3 orders of magnitude greater than the modern hydrothermal ridge flux $\left(9-1300 \times 10^{9} \mathrm{~mol} \mathrm{yr}^{-1}\right)^{38}$. Glass alteration also results in uptake of $\mathrm{CO}_{2}$ from solution ${ }^{39}$ according to the approximate reaction:

$$
\begin{aligned}
\text { Reactive silicates }+2 \mathrm{CO}_{2}+\mathrm{H}_{2} \mathrm{O} \rightarrow 2 \mathrm{HCO}_{3}^{-} & + \text {dissolved cations } \\
& + \text { clay minerals }
\end{aligned}
$$

Ca forms most of the charge balance carried by the dissolved cation budget released to solution during glass alteration. $\mathrm{Mg}$ and $\mathrm{Na}$ contribute most of the remainder, along with a small uptake of $\mathrm{K}^{24}$. Thus, a combined $\mathrm{Ca}, \mathrm{Mg}$ and $\mathrm{Na}(-\mathrm{K})$ flux of approximately $2 \times 10^{13} \mathrm{~mol} \mathrm{yr}^{-1}$ during hyaloclastite alteration results in uptake of $4 \times 10^{13} \mathrm{~mol} \mathrm{yr}^{-1}$ of $\mathrm{CO}_{2}$. By comparison, the global rate of continental silicate weathering is $1.2 \times 10^{13} \mathrm{~mol} \mathrm{yr}^{-1}$ of $\mathrm{CO}_{2}$ $\left(\right.$ ref. $\left.{ }^{40}\right)$.

Hyaloclastite alteration in an ice-covered ocean provides a major source of alkalinity - additional to that provided by the long-term alteration of the oceanic crust ${ }^{20}$ _ driving up carbonate production immediately after Snowball Earth glaciations. The cap carbonate sequences that formed globally on con- 
tinental margins, typically overlying glacial diamictites ${ }^{2,12}$, are commonly attributed to enhanced terrestrial weathering of carbonate-rich sediments during and after glaciation ${ }^{14,15}$. However, to achieve observed cap carbonate thicknesses (some $>100 \mathrm{~m}$, Figs 3c,d) would require extreme levels of terrestrial weathering, delivering $\sim 10^{2}-10^{3}$ times the present annual supply of dissolved cations to the oceans ${ }^{29}$. Continental runoff during the post-snowball greenhouse $\left(400 \times\right.$ modern $\left.p \mathrm{CO}_{2}\right)$ likely produced $\sim 1.2$ times the modern riverine runoff $^{16}$, suggesting subaerial weathering alone cannot explain cap carbonate production $^{29}$.

We propose that under near-global ice cover, which suppresses normal removal processes, a prolonged state of hyaloclastite eruption and alteration would supersaturate seawater with $\mathrm{Ca}^{2+}$ and $\mathrm{Mg}^{2+}$. This is consistent with evidence for rapid carbonate sedimentation (spontaneous nucleation) following glaciations ${ }^{2,12,15}$. The question is whether requisite degrees of supersaturation are feasible over such prolonged timescales (order $10 \mathrm{Myr}$ ). At our maximum estimated discharge rate (the trivial case with no initial dissolved $\mathrm{Ca}^{2+}$ or $\mathrm{Mg}^{2+}$ ) the ocean reaches saturation within 1-3 $\mathrm{Myr}\left(\mathrm{Ca}^{2+}\right.$ and $\mathrm{Mg}^{2+}$, respectively). A 10 Myr glaciation could therefore yield degrees of supersaturation exceeding $12 \times\left(\mathrm{Ca}^{2+}\right)$ and $3 \times\left(\mathrm{Mg}^{2+}\right)$, certainly feasible in the light of observations of experimental solutions ${ }^{41}$, geological fluids ${ }^{42}$, and the present-day surface ocean ${ }^{43}$. In the glacial aftermath, conditions become more favourable for rapid precipitation: higher ocean temperatures, renewed photosynthesis, increased primary productivity, enhanced atmospheric $\mathrm{CO}_{2}$ exchange, and importantly, resumption of particle settling providing carbonate condensation nuclei. Volcanism before and after glaciations (Fig. 2; SI Table 1) will also have contributed to carbonate deposition, although in the absence of ice cover (limiting build-up in the ocean) would occur more gradually. Combined with the rate-limiting influence of platform subsidence ${ }^{2}$, this may explain slower sedimentation rates inferred for some Marinoan carbonate sequences ${ }^{17,18}$.

In an ice-covered ocean, limited atmospheric exchange leads to rapid conversion of dissolved $\mathrm{CO}_{2}$ to bicarbonate $\left(\mathrm{HCO}_{3}{ }^{-}\right.$, which constitutes the majority of seawater DIC) by equation [1]. However, hyaloclastite formation is also associated with $\mathrm{CO}_{2}$ degassing from erupted basalt, particularly at shallow depths. Assuming a pre-eruptive $\mathrm{CO}_{2}$ concentration of $0.5 \mathrm{wt} \%$ in the basalts and total degassing, hyaloclastite emplacement could release $\sim 0.03-1.3 \times 10^{12} \mathrm{~mol} \mathrm{yr}^{-1}$ $\mathrm{CO}_{2}$, broadly consistent with the ridge flux $\left(\sim 0.8 \times 10^{12} \mathrm{~mol} \mathrm{yr}^{-1}\right)$ assumed for the 'snowball' ocean ${ }^{2}$. This is not a completely closed system: cracks in seaice ${ }^{44}$ will have permitted some $\mathrm{CO}_{2}$ outgassing. Equally, ice-free regions will have allowed $\mathrm{CO}_{2}$ ingassing during a period when atmospheric $\mathrm{CO}_{2}$ levels due to subaerial volcanism ${ }^{2}$ ultimately exceeded present-day levels by two to three orders of magnitude ${ }^{11}$, a net $\mathrm{CO}_{2}$ gain. The long-term $\mathrm{CO}_{2}$ input from volcanism and hydrothermal activity can explain mantle-like $\delta^{13} \mathrm{C}$ signatures $(-6 \pm$ $1 \%$ ) observed in many cap carbonates ${ }^{2,12,13}$. Stratigraphic or localisedcarbon- 
ate $\delta^{13} \mathrm{C}$ increases ${ }^{29}$ may reflect increases in biological productivity, organic carbon burial, and intensified subaerial carbonate weathering - all expected in the snowball aftermath ${ }^{15,19}$.

Some post-Sturtian cap carbonates exhibit ${ }^{187} \mathrm{Os} /{ }^{188} \mathrm{Os}$ ratios consistent with continental inputs ${ }^{33}$, again expected during a post-glacial weathering spike. However, many cap carbonates exhibit only minor shifts in ${ }^{87} \mathrm{Sr} /{ }^{86} \mathrm{Sr}$ (refs. ${ }^{15,29}$ ), suggesting that enhanced terrestrial weathering was not dominant in their production ${ }^{29}$. Pre-Marinoan carbonates (800-650 Ma) exhibit relatively low ${ }^{87} \mathrm{Sr} /{ }^{86} \mathrm{Sr}$ (ref. ${ }^{45}$ ), compatible with significant hydrothermal ridge contributions ${ }^{46}$, which will progressively dominate the Sr isotope inventory in seawater under ice cover with much reduced continental runoff ${ }^{15}$. Further, widespread enrichment of heavy rare earth elements (REE) and positive Eu and Y anomalies in Sturtian ${ }^{47}$ and Marinoan ${ }^{48}$ cap carbonates can be explained by alteration of mid-ocean ridge basalts and wholesale mixing of hydrothermal fluids in the ocean ${ }^{48,49}$.

The maximum simulated $\mathrm{Ca}^{2+}$ flux (Fig. 3a) would yield $\sim 18.5$ m-thick buildup (mean estimate $2 \mathrm{~m}$, median $1.2 \mathrm{~m}$, Fig. 3c) of carbonate over an area equivalent to the present-day continental shelf for every $10^{6}$ years of ridge formation. Given the Sturtian (diachronous ${ }^{50}$ ) and Marinoan glaciations persisted for $\sim 55 \mathrm{Myr}^{33}$ and $\sim 12 \mathrm{Myr}^{51}$, respectively, these accumulations are of the same order as observed cap carbonates, typically metres to tens of metres thick $^{12}$ (Fig. 3c).

Ridge alteration could produce magnesium fluxes of the order $1-6 \times 10^{12} \mathrm{~mol}$ $\mathrm{yr}^{-1}$ (Fig. 3b and SI Table 2; modern riverine $\mathrm{Mg}$ flux is $5.1 \times 10^{12} \mathrm{~mol} \mathrm{yr}^{-1}$ ) ${ }^{37}$, potentially contributing $\sim 2-15 \mathrm{~m}$-thick dolostone for every $10^{6}$ years of ridge formation. Accordingly, our model suggests the Marinoan event could yield 20-150 m-thick dolostone, consistent with observed global mean and maximum thicknesses of $18.5 \mathrm{~m}$ and $175 \mathrm{~m}$ respectively ${ }^{52}$ (Fig. 3d). On timescales typically associated with deglaciation (c. $10 \mathrm{kyr}$ ), continental weathering is only likely to supply enough $\mathrm{Mg}^{2+}$ to produce a $\sim 0.5 \mathrm{~m}$ thick cap dolostone ${ }^{16}$. Therefore our hypothesis provides an important or even dominant additional source of $\mathrm{Ca}^{2+}$ and $\mathrm{Mg}^{2+}$, and can help explain not only the qualitative association of cap carbonate and dolostone sequences with Snowball Earth episodes, but also observed thicknesses of these deposits.

Although up to $90 \% \mathrm{P}_{2} \mathrm{O}_{5}$ in fresh basaltic glass can be released during alteration $^{25}$, we assume a conservative $20-80 \%$ loss, based on modern palagonites ${ }^{24}$. Simulations show that high spreading rates $\left(>100 \mathrm{~mm} \mathrm{yr}^{-1}\right)$ coupled with extensive ridges $\left(>15 \times 10^{3} \mathrm{~km}\right)$, could yield dissolved phosphorus fluxes up to $7 \times 10^{11} \mathrm{~mol} \mathrm{yr}^{-1}$ (Fig. 4a; SI Fig. 3b), roughly 20 times the modern dissolved riverine flux $\left(3.1 \times 10^{10} \mathrm{~mol} \mathrm{yr}^{-1}\right)^{37}$. For the full simulation (SI Table 2), the median phosphorus flux $\left(3.7 \times 10^{10} \mathrm{~mol} \mathrm{yr}^{-1}\right)$ is comparable to the modern 
riverine contribution, and the high hyaloclastite production scenario yields a flux $\sim 7$ times greater $\left(2.3 \times 10^{11} \mathrm{~mol} \mathrm{yr}^{-1} ;\right.$ Fig. $\left.4 \mathrm{~b}\right)$. Assuming full unzipping and substantial secondary mineralisation losses (SI Fig. 4), there is $\sim 70 \%$ probability that P-influx would exceed the modern riverine flux (SI Fig. 5). In the modern ocean, phosphate sorption onto ferric oxyhydroxides represents a significant sink, but this is thought to have been of minor importance in the Neoproterozoic due to high oceanic silicic acid concentrations - as silica hydroxides suppress phosphate sorption onto ferric oxyhydroxides ${ }^{19}$.

Hyaloclastite alteration during ridge unzipping provides a viable mechanism to account for anomalously high seawater phosphorus levels (5-10 times Phanerozoic levels, according to P:Fe ratios in sedimentary iron formations) ${ }^{19}$ inferred for Snowball Earth episodes. This 'excess phosphate ocean' has been attributed to enhanced weathering of glacial deposits during the 'snowball' thaw phase ${ }^{19}$. Although relevant, post-glacial weathering would be expected to yield a relatively short-lived $(\sim 10-100 \mathrm{kyr})^{16}$ increase in phosphate, and could be problematic in view of the low solubility of apatite. Our model provides a mechanism for producing high dissolved phosphorus levels that, in the absence of biological removal, could persist over $\sim 10-100$ Myr (Fig. 2), over repeated cycles (i.e., protracted opening of the Proto-Pacific followed by Iapetus in Ediacaran times; Fig. 1b) ${ }^{3}$. This process operated independently, and in addition to other mechanisms, such as biotic enhancement of apatite weathering linked to increased weathering rates via microbial colonisation of the land ${ }^{53}$, and subaerial weathering of large igneous provinces ${ }^{54}$ (notably during the Tonian period; Fig. 2).

The shallow ridge can also contribute to relatively high dissolved oceanic silicic acid concentrations inferred for the Neoproterozoic ${ }^{19}$, and the $\mathrm{SiO}_{2}$-rich $(\sim 30-55 \%)$ banded iron formations (BIF) that served as a (local) silica sink during the Sturtian ${ }^{30,55}$, and possibly, but not ostensibly, during the Marinoan $^{55}$ glaciations. Basaltic glass alteration results in loss of an average $\sim 16$ wt $\% \mathrm{SiO}_{2}{ }^{24}$ (potentially up to $\left.50 \%\right)^{25}$, thus contributing up to $10 \times$ the current riverine flux of $\sim 6.4 \times 10^{12} \mathrm{~mol} \mathrm{yr}^{-1}$ (ref. ${ }^{37}$ ) to the ocean during extensive hyaloclastite alteration (SI Table 2, SI Fig. 6b). High hydrothermal Fe fluxes ${ }^{48}$ are expected in our low hydrostatic pressure regime ${ }^{56}$, and a dominance of hydrothermal inputs is supported by mantle-like $\mathrm{Nd}$ and $\mathrm{Pb}$ isotope signatures observed in some BIFs ${ }^{30}$. Thus, our hypothesis might help elucidate the common association between BIFs and mafic volcanics ${ }^{55}$, although this requires further validation, particularly given the localised nature of many BIFs. 


\section{Consequences of a shallow ridge system}

The discovery that Earth experienced near-total ice cover for prolonged periods in the Neoproterozoic has greatly enhanced understanding of Earth history, but critical aspects remain unresolved. We demonstrate how enhanced shallow marine volcanic activity, persisting for $>20$ Myr in the absence of most biological removal processes, would have driven major changes in ocean chemistry. Our shallow ridge hypothesis advances understanding of Snowball Earth events, qualitatively and quantitatively explaining many enigmatic features including: increased ocean alkalinity; ${ }^{13} \mathrm{C}$-depleted cap carbonate sequences; and high silica concentrations manifest in banded iron formations.

Our hypothesis provides a critical quantitative explanation for unusually high dissolved phosphate inputs to late Proterozoic oceans. This enhanced supply likely drove the increase in primary productivity required to generate the large rise in atmospheric oxygen levels that occurred in the wake of Snowball Earth events $^{19}$. We infer that shallow ridge volcanism associated with the ProtoPacific and Iapetan rifts also prompted oxidation of the Ediacaran ocean ${ }^{57}$, which would have facilitated the emergence of multicellular life.

\section{Methods}

Methods and any associated references are available in the online version of the paper.

\section{References}

1. Kirschvink, J. L. Late Proterozoic low latitude glaciation: The Snowball Earth. In The Proterozoic Biosphere: A Multidisciplinary Study, Schopf, J. W. and Klein, C., editors, 51-52. Cambridge Univ. Press, New York (1992).

2. Hoffman, P. F., Kaufman, A. J., Halverson, G. P., and Schrag, D. P. A Neoproterozoic Snowball Earth. Science 281, 1342-1346 (1998).

3. Eyles, N. and Januszczak, N. 'Zipper-rift': a tectonic model for Neoproterozoic glaciations during the breakup of Rodinia after 750 Ma. EarthScience Reviews 65, 1-73 (2004).

4. Donnadieu, Y., Godderis, Y., Ramstein, G., Nedelec, A., and Meert, J. A 'snowball earth' climate triggered by continental break-up through changes in runoff. Nature 428, 303-306 (2004).

5. Torsvik, T. H., Smethurst, M. A., Meert, J. G., Van der Voo, R., McKerrow, W. S., Brasier, M. D., Sturt, B. A., and Walderhaug, H. J. Con- 
tinental break-up and collision in the Neoproterozoic and Palaeozoic - A tale of Baltica and Laurentia. Earth-Science Reviews 40, 229-258 (1996).

6. Macdonald, F. A., Schmitz, M. D., Crowley, J. L., Roots, C. F., Jones, D. S., Maloof, A. C., Strauss, J. V., Cohen, P. A., Johnston, D. T., and Schrag, D. P. Calibrating the Cryogenian. Science 327, 1241-1243, 03 (2010).

7. Cooper, A. F., Maas, R., Scott, J. M., and Barber, A. J. W. Dating of volcanism and sedimentation in the Skelton Group, Transantarctic Mountains: Implications for the Rodinia-Gondwana transition in southern Victoria Land, Antarctica. Geological Society of America Bulletin 123, 681$702(2011)$.

8. O'Brien, T. M. and van der Pluijm, B. A. Timing of Iapetus Ocean rifting from Ar geochronology of pseudotachylytes in the St. Lawrence rift system of southern Quebec. Geology 40, 443-446 (2012).

9. Van Staal, C. R., Dewey, J. F., MacNiocaill, C., and McKerrow, W. S. The Cambrian-Silurian tectonic evolution of the northern Appalachians and British Caledonides: history of a complex, west and southwest Pacifictype segment of Iapetus. Geological Society, London, Special Publications 143, 197-242 (1998).

10. Goddéris, Y., Donnadieu, Y., Nédélec, A., Dupré, B., Dessert, C., Grard, A., Ramstein, G., and François, L. M. The Sturtian 'snowball' glaciation: fire and ice. Earth and Planetary Science Letters 211, 1-12 (2003).

11. Pierrehumbert, R. T. High levels of atmospheric carbon dioxide necessary for the termination of global glaciation. Nature 429, 646-649 (2004).

12. Hoffman, P. F. and Schrag, D. P. The snowball Earth hypothesis: testing the limits of global change. Terra Nova 14, 129-155 (2002).

13. Halverson, G. P. and Shields-Zhou, G. Chapter 4 Chemostratigraphy and the Neoproterozoic glaciations. Geological Society, London, Memoirs 36(1), 51-66 (2011).

14. Fairchild, I. J. Balmy Shores and Icy Wastes: The Paradox of Carbonates Associated with Glacial Deposits in Neoproterozoic Times. Sedimentology Review 1, 1-16 (1993).

15. Higgins, J. A. and Schrag, D. P. Aftermath of a snowball Earth. Geochemistry, Geophysics, Geosystems 4, 1028 (2003).

16. Le Hir, G., Donnadieu, Y., Goddéris, Y., Pierrehumbert, R. T., Halverson, G. P., Macouin, M., Nédélec, A., and Ramstein, G. The snowball Earth aftermath: Exploring the limits of continental weathering processes. Earth and Planetary Science Letters 277, 453-463 (2009).

17. Trindade, R. I. F., Font, E., D'Agrella-Filho, M. S., Nogueira, A. C. R., and Riccomini, C. Low-latitude and multiple geomagnetic reversals in the Neoproterozoic Puga cap carbonate, Amazon craton. Terra Nova 15, 441-446 (2003).

18. Kennedy, M. J. and Christie-Blick, N. Condensation origin for Neoproterozoic cap carbonates during deglaciation. Geology 39, 319-322 (2011). 19. Planavsky, N. J., Rouxel, O. J., Bekker, A., Lalonde, S. V., Konhauser, 
K. O., Reinhard, C. T., and Lyons, T. W. The evolution of the marine phosphate reservoir. Nature 467, 1088-1090 (2010).

20. Le Hir, G., Ramstein, G., Donnadieu, Y., and Goddéris, Y. Scenario for the evolution of atmospheric pCO2 during a snowball Earth. Geology 36, 47-50 (2008).

21. Storey, M., Duncan, R. A., and Tegner, C. Timing and duration of volcanism in the North Atlantic Igneous Province: Implications for geodynamics and links to the Iceland hotspot. Chemical Geology 241, 264-281 (2007).

22. Planke, S., Symonds, P. A., Alvestad, E., and Skogseid, J. Seismic volcanostratigraphy of large-volume basaltic extrusive complexes on rifted margins. Journal of Geophysical Research 105, 19335-19351. (2000).

23. Batiza, R. and White, J. D. L. Submarine lavas and hyaloclastite. In Encyclopedia of Volcanoes, Sigurdsson, H., editor, 361-381. Academic Press, San Diego (2000).

24. Stroncik, N. A. and Schmincke, H. U. Palagonite - a review. International Journal of Earth Sciences 91, 680-697 (2002).

25. Staudigel, H. and Hart, S. R. Alteration of basaltic glass: mechanisms and significance for the oceanic crust-sea water budget. Geochimica et Cosmochimica Acta 47, 337-350 (1983).

26. Brady, P. V. and Gíslason, S. R. Seafloor weathering controls on atmospheric $\mathrm{CO}_{2}$ and global climate. Geochimica et Cosmochimica Acta 61, 965-973 (1987).

27. Mottl, M. J. and Wheat, C. G. Hydrothermal circulation through midocean ridge flanks: Fluxes of heat and magnesium. Geochimica et Cosmochimica Acta 58, 2225-2237 (1994).

28. Jakobsson, S. P. Environmental factors controlling the palagonitization of the tephra of the Surtsey volcanic island, Iceland. Bull. Geol. Soc. Denmark 27, 91-105 (1978).

29. Kennedy, M. J., Christie-Blick, N., and Prave, A. R. Carbon isotopic composition of Neoproterozoic glacial carbonates as a test of paleoceanographic models for snowball Earth phenomena. Geology 29, 1135-1138 (2001).

30. Stern, R. J., Mukherjee, S. K., Miller, N. R., Ali, K., and Johnson, P. R. $\sim 750$ Ma banded iron formation from the Arabian-Nubian ShieldImplications for understanding neoproterozoic tectonics, volcanism, and climate change. Precambrian Research 239, 79-94 (2013).

31. Cox, G. M., Roots, C. F., Halverson, G. P., Minarik, W. G., Macdonald, F. A., and Hubert-Theou, L. Mount Harper Volcanic Complex, Ogilvie Mountains: A far-flung occurrence of the Franklin Igneous Event. In Yukon Exploration and Geology 2012, MacFarlane, K. E., Nordling, M. G., and Sack, P. J., editors, 19-36. Yukon Geological Survey (2013).

32. Calver, C. R., Black, L. P., Everard, J. L., and Seymour, D. B. U-Pb zircon age constraints on late Neoproterozoic glaciation in Tasmania. Geology $\mathbf{3 2}$, 893-896 (2004).

33. Rooney, A. D., Macdonald, F. A., Strauss, J. V., Dudás, F. Ö., Hall- 
mann, C., and Selby, D. Re-Os geochronology and coupled Os-Sr isotope constraints on the Sturtian snowball Earth. Proceedings of the National Academy of Sciences 111, 51-56 (2014).

34. Reid, I. and Jackson, H. R. Oceanic spreading rate and crustal thickness. Marine Geophysical Researches 5, 165-172 (1981).

35. Wilson, D. S. Fastest known spreading on the Miocene Cocos-Pacific Plate Boundary. Geophysical Research Letters 23, 3003-3006 (1996).

36. Alt, J. C. Subseafloor Processes in Mid-Ocean Ridge Hydrothermal Systems. In Seafloor Hydrothermal Systems: Physical, Chemical, Biological, and Geological Interactions, Humphris, S. E., Zierenberg, R. A., Mullineaux, L. S., and Thomson, R. E., editors, number 91, 85-114. American Geophysical Union (1995).

37. Berner, E. K. and Berner, R. A. Global Environment: Water, Air, and Geochemical Cycles. Princeton University Press, 2 edition, (2012).

38. Elderfield, H. and Schultz, A. Mid-ocean ridge hydrothermal fluxes and the chemical composition of the ocean. Annual Review of Earth and Planetary Sciences 24, 191-224 (1996).

39. Wallmann, K., Aloisi, G., Haeckel, M., Tishchenko, P., Pavlova, G., Greinert, J., Kutterolf, S., and Eisenhauer, A. Silicate weathering in anoxic marine sediments. Geochimica et Cosmochimica Acta 72, 2895-2918 (2008).

40. Gaillardet, J., Dupré, B., Louvat, P., and Allègre, C. J. Global silicate weathering and $\mathrm{CO}_{2}$ consumption rates deduced from the chemistry of large rivers. Chemical Geology 159, 3-30 (1999).

41. Pokrovsky, O. Precipitation of calcium and magnesium carbonates from homogeneous supersaturated solutions. Journal of Crystal Growth 186, $233-239$ (1998).

42. Compton, J. S. Degree of supersaturation and precipitation of organogenic dolomite. Geology 16, 318-321 (1988).

43. Pokrovsky, O. S. Kinetics of $\mathrm{CaCO}_{3}$ homogeneous precipitation in seawater. Mineralogical Magazine 58A, 738-739 (1994).

44. Allen, P. A. and Etienne, J. L. Sedimentary challenge to Snowball Earth. Nature Geosci 1, 817-825 (2008).

45. Kaufman, A. J., Jacobsen, S. B., and Knoll, A. H. The Vendian record of $\mathrm{Sr}$ and $\mathrm{C}$ isotopic variations in seawater: Implications for tectonics and paleoclimate. Earth and Planetary Science Letters 120, 409-430 (1993).

46. Halverson, G. P., Dudás, F. Ö., Maloof, A. C., and Bowring, S. A. Evolution of the $87 \mathrm{Sr} / 86 \mathrm{Sr}$ composition of Neoproterozoic seawater. Palaeogeography, Palaeoclimatology, Palaeoecology 256, 103-129 (2007).

47. Meyer, E. E., Quicksall, A. N., Landis, J. D., Link, P. K., and Bostick, B. C. Trace and rare earth elemental investigation of a Sturtian cap carbonate, Pocatello, Idaho: Evidence for ocean redox conditions before and during carbonate deposition. Precambrian Research 192-195, 89-106 (2012).

48. Huang, J., Chu, X., Jiang, G., Feng, L., and Chang, H. Hydrothermal origin of elevated iron, manganese and redox-sensitive trace elements in 
the c. 635 Ma Doushantuo cap carbonate. Journal of the Geological Society 168, 805-816 (2011).

49. Young, G. M. Precambrian supercontinents, glaciations, atmospheric oxygenation, metazoan evolution and an impact that may have changed the second half of Earth history. Geoscience Frontiers 4, 247-261 (2013).

50. Kendall, B., Creaser, R. A., and Selby, D. Re-Os geochronology of postglacial black shales in Australia: Constraints on the timing of "Sturtian" glaciation. Geology 34, 729-732 (2006).

51. Bodiselitsch, B., Koeberl, C., Master, S., and Reimold, W. U. Estimating duration and intensity of Neoproterozoic snowball glaciations from Ir anomalies. Science 308, 239-242 (2005).

52. Hoffman, P. F., Halverson, G. P., Domack, E. W., Husson, J. M., Higgins, J. A., and Schrag, D. P. Are basal Ediacaran (635 Ma) post-glacial "cap dolostones" diachronous? Earth and Planetary Science Letters 258, 114131 (2007).

53. Lenton, T. M. and Watson, A. J. Biotic enhancement of weathering, atmospheric oxygen and carbon dioxide in the Neoproterozoic. Geophysical Research Letters 31, L05202 (2004).

54. Horton, F. Did phosphorus derived from the weathering of large igneous provinces fertilize the Neoproterozoic ocean? Geochemistry, Geophysics, Geosystems 16, 1723-1738 (2015).

55. Cox, G. M., Halverson, G. P., Minarik, W. G., Heron, D. P. L., Macdonald, F. A., Bellefroid, E. J., and Strauss, J. V. Neoproterozoic iron formation: An evaluation of its temporal, environmental and tectonic significance. Chemical Geology 362, 232 - 249 (2013).

56. Kump, L. R. and Seyfried Jr., W. E. Hydrothermal Fe fluxes during the Precambrian: Effect of low oceanic sulfate concentrations and low hydrostatic pressure on the composition of black smokers. Earth and Planetary Science Letters 235, 654-662 (2005).

57. Fike, D. A., Grotzinger, J. P., Pratt, L. M., and Summons, R. E. Oxidation of the Ediacaran Ocean. Nature 444, 744-747 (2006).

\section{Acknowledgements}

E.J.R. acknowledges Australian Research Council Laureate Fellowship FL1201 00050. We are grateful to R.S.J. Sparks, R.N. Taylor, C.N. Trueman, T. Lenton, I. Fairchild and G. Shields-Zhou for helpful discussions and suggestions. Supplementary Information figure 1 was illustrated by Gary Hincks. 


\section{${ }_{513}$ Author contributions}

${ }_{514}$ The research was conceived and managed by T.G. T.H. developed and per-

515 formed simulations with inputs from T.G., T.T., M.R.P. and E.J.R. The 516 manuscript was written by T.G. with important contributions from all co517 authors.

${ }_{518}$ Additional information

519 Supplementary information is available in the online version of the paper.

${ }_{520}$ Reprints and permission information is available online at www.nature.com/

521 reprints. Correspondence and requests for materials should be addressed to 522 T.G.

${ }_{523}$ Competing financial interests

${ }_{524}$ The authors declare no competing financial interests. 


\section{Figure captions}

Figure 1 | Evolution of spreading ridge systems during the late Neoproterozoic. a. Continental reconstructions at $\sim 750$ Ma showing location of the Proto-Pacific rift system, and $\mathbf{b}$, at $\sim 600$ Ma showing inferred location of the Iapetan rift (modified after ref. ${ }^{10}$ ). c. During the early phase of plume magmatism ( 800 Ma), volcanism was largely subaerial (Supplementary Information Table 1); however, as rifting occurred, the main axis of volcanism submerged below sea-level resulting in the formation of the Proto-Pacific (and Iapetus at $\sim 600 \mathrm{Ma}$ ) and a sustained phase of shallow marine volcanism. d. Under these conditions (shown here prior to glaciation), hyaloclastites are formed preferentially by quenching and explosive shattering of lava in contact with seawater, forming 'fresh' highly alterable glasses.

Figure 2 | Summary of major global volcanic events during the Tonian, Cryogenian and early Ediacaran periods, in relation to major glaciations (blue) and continental breakup events (beige). Red bars signify major volcanic events involving extensive hyaloclastite emplacement (see Supplementary Information Table 1 for more information); note LIP: Large Igneous Province; ANS: Arabian-Nubian Shield.

Figure 3 | Monte Carlo simulations showing estimated $\mathrm{Ca}$ and $\mathrm{Mg}$ fluxes into the 'snowball' ocean, and resulting thicknesses of carbonate and dolostone. Input parameter ranges are defined in Table 1. Note the logarithmic scales for the flux axes in (a) and (b). a. Flux of Ca, accounting for a variable percentage lost to $\mathrm{CaCO}_{3}$ cementation. b. Flux of $\mathrm{Mg}$, accounting for in situ dolomite cementation; lines denote the modern annual riverine dissolved $\mathrm{Ca}$ and $\mathrm{Mg}$ fluxes for comparison. Note that (a) and (b) represent the full simulation (SI Table 2). c. \& d. Probability of exceedance for cap carbonate $(\mathbf{c})$ and dolostone $(\mathbf{d})$ thicknesses resulting from accumulation of $\mathrm{Ca}$ and $\mathrm{Mg}$, respectively, in seawater over the course of a Snowball Earth episode of 10 Myr duration. The shaded areas show typical (grey) and maximum (light grey) observed thicknesses: 3-30 m for $\mathrm{CaCO}_{3}$ (maximum $400 \mathrm{~m})^{12}$; and $1.5-38 \mathrm{~m}$ for $\mathrm{CaMg}\left(\mathrm{CO}_{3}\right)_{2}$ (maximum $\left.>175 \mathrm{~m}\right)^{52}$. The curves show the probability, based on all simulations, that a given thickness will be exceeded; e.g. for the full simulation (black line) shown in (c), more than $40 \%$ of simulations exceed the observed mean of carbonate thickness $(\sim 18.5 \mathrm{~m})$, and $20 \%$ exceed $30 \mathrm{~m}$. Curves are shown for the full simulation (black line) and three alternative ridge productivity scenarios (I-III) defined in SI Table 2 .

Figure 4 | Monte Carlo simulations for estimated phosphorus fluxes into a typical 'snowball' ocean. Input parameter ranges are defined in Table 1. Note the logarithmic scale for the flux axis in (a). a. Flux of P, 
accounting for CFA cementation (Supplementary Information Fig. 4). Solid line denotes the modern annual dissolved riverine $\mathrm{P}$ flux for comparison ${ }^{37}$. b. Probability of exceedance of phosphorus fluxes computed for the full simulation (black line) and three alternative ridge productivity scenarios (I-III) defined in SI Table 2 (see Supplementary Information Fig. 5 for the effects of CFA cementation).

\section{Tables}

Table 1 | Ranges of parameter values used in the Monte Carlo simulations. See Methods for further details.

\begin{tabular}{|c|c|c|}
\hline Sampled parameters & Minimum value & Maximum value \\
\hline$R=$ Ridge length $(\mathrm{m})$ (ref. ${ }^{3}$ ) & $0.5 \times 10^{7}$ & $2 \times 10^{7}$ \\
\hline$S=$ Spreading rate $\left(\mathrm{m} \mathrm{yr}^{-1}\right)\left(\operatorname{refs}^{5,34,35}\right)$ & 0.05 & 0.2 \\
\hline$D=$ Alteration (penetration) depth $(\mathrm{m})\left(\right.$ ref. $\left.{ }^{36}\right)$ & 100 & 1500 \\
\hline$H_{s}=$ Fraction hyaloclastite from $0-1 \mathrm{~km}$ depth (ref. ${ }^{23}$, Methods) & 0.5 & 0.8 \\
\hline$\Phi_{s}=$ Hyaloclastite porosity $(\Phi)$ from $0-1 \mathrm{~km}$ depth $\left(\right.$ ref. $\left.^{36}\right)$ & 0.12 & 0.3 \\
\hline$H_{d}=$ Fraction hyaloclastite from $1-1.5 \mathrm{~km}$ depth (ref. ${ }^{23}$, Methods) & 0.1 & 0.2 \\
\hline$\Phi_{d}=$ Hyaloclastite porosity $(\Phi)$ from $1-1.5 \mathrm{~km}$ depth (ref. ${ }^{36}$ ) & 0.08 & 0.12 \\
\hline$P=$ Altered (palagonite) fraction (ref. ${ }^{24,25}$ ) & 0.6 & 1.0 \\
\hline$L_{\mathrm{CaO}}=$ Fraction $\mathrm{CaO}$ loss $\left(\right.$ ref. $^{24,25}$ ) & 0.04 & 0.1 \\
\hline$L_{\mathrm{SiO} 2}=$ Fraction $\mathrm{SiO}_{2}$ loss $\left(\right.$ ref. ${ }^{24,25}$ ) & 0.1 & 0.3 \\
\hline$L_{P 2 O 5}=$ Fraction $\mathrm{P}_{2} \mathrm{O}_{5}$ loss (ref. $\left.{ }^{24,25}\right)$ & 0.002 & 0.006 \\
\hline$L_{M g O}=$ Fraction $\mathrm{MgO}$ loss (ref. ${ }^{24,25}$ ) & 0.027 & 0.067 \\
\hline$C_{\mathrm{CaO}}, C_{C F A}, C_{\mathrm{SiO} 2}, C_{\mathrm{MgO}}=$ Cement phase (as fraction of element loss) & 0 & 1.0 \\
\hline
\end{tabular}

\section{Methods}

Deposition of chemically easily weathered hyaloclastites will cause a major influx of $\mathrm{Ca}, \mathrm{P}, \mathrm{Si}$ and $\mathrm{Mg}$, among other elements, into the oceans. Monte Carlo simulations were performed to capture the variation in the main depositional and weathering processes. Input parameters were sampled independently from uniform distributions over fixed intervals, given in Table 1 (using the Scythe C++ Statistical Library ${ }^{58}$ ). Uniform distributions were chosen as these yield the most conservative estimate of uncertainty, and there is not enough observational evidence to justify a more tightly constrained distribution (e.g. specifying a central weighting would require knowledge of the mean and variance of the distribution). The model generates a volume of hyaloclastite $\left(\mathrm{m}^{3} \mathrm{yr}^{-1}\right)$, given a sampled total ridge length $(R)$, spreading rate $(S)$ and cumulative deposit thickness $(D)$. The annual elemental flux estimates (Figs $3 \mathrm{a}, \mathrm{b}$ ) are based on annual ridge output (fresh material along the hot ridge 
axis). Any subsequent contributions from previously unaltered erupted products are conservatively excluded. Long-term accumulation in the ocean (over the period of active rifting) (Figs 3c,d) is estimated by summing the (variable) annual elemental contributions over a period of $10 \mathrm{Myr}$, again a conservative estimate of the time during which we would expect extensive hyaloclastite formation and alteration. We therefore account for short-term fluctuations in calculating cumulative oceanic inputs, and potential deposit (cap carbonate) thickness. The ridge length is varied from $5-20 \times 10^{3} \mathrm{~km}$ to simulate progressive breakup of Rodinia around the perimeter of Laurentia ${ }^{59}$. The spreading rate is varied from $0.05-0.2 \mathrm{~m} \mathrm{yr}^{-1}$ to simulate moderate ${ }^{60}$ to fast ${ }^{61}$ rates expected during breakup ${ }^{62}$. Here, the higher rate is not unreasonable, given that Laurentia is known to have moved at speeds of $0.2 \mathrm{~m} \mathrm{yr}^{-1}$ during the Ediacaran ${ }^{63}$.

Conservatively we consider a range of alteration penetration depths from 100-1500 $\mathrm{m}^{64}$. Through analogy with ophiolite sequences, hyaloclastite deposit thickness and other parameters will vary with depth. In the upper kilometre, the hyaloclastite (i.e. pyroclastic) fraction $\left(H_{s}\right)$ ranges from $50-80 \%$ of the total bed depth, reflecting the observed tendency for enhanced explosivity in shallow water conditions $(<1$ $\mathrm{km})^{65,66}$. Below $1 \mathrm{~km}$ hyaloclastites are expected to be less extensive (10-20\% of bed depth) due to an overriding tendency for intrusive processes at depth in ocean crust $^{64}$. Again conservatively we assume no hyaloclastite below $1.5 \mathrm{~km}$. These estimates are consistent with deposits observed along analogous rifted margins ${ }^{67-70}$. The equations used in simulations are given below (for definitions, see Table 1 and Supplementary Information Tables $3 \& 4$ ).

Equation [2] gives the total thickness of hyaloclastite deposits, and [3] the corresponding mass of hyaloclastite formed per year along the length of the ridge. Equation [4] gives the approximate mass of $\mathrm{P}_{2} \mathrm{O}_{5}, \mathrm{CaO}, \mathrm{SiO}_{2}$ or $\mathrm{MgO}$ lost due to hyaloclastite alteration. This can either be released to the ocean or consumed during cement formation.

$$
\begin{aligned}
& \left.\begin{array}{l}
t_{s}=D H_{s} \\
t_{d}=0
\end{array}\right\} \mathrm{D} \leq 1000(\mathrm{~m}) \\
& \left.\begin{array}{l}
t_{s}=1000 H_{s} \\
t_{d}=(D-1000) H_{d}
\end{array}\right\} \mathrm{D}>1000(\mathrm{~m}) \\
& m_{\text {total }}=R S \rho_{\text {crust }}\left(t_{s}\left(1-\Phi_{s}\right)+t_{d}\left(1-\Phi_{d}\right)\right) \\
& m_{\mathrm{P} 2 \mathrm{O} 5 / \mathrm{CaO} / \mathrm{SiO} 2 / \mathrm{MgO}}=m_{\text {total }} P L_{P 2 \mathrm{O} 5 / \mathrm{CaO} / \mathrm{SiO} 2 / \mathrm{MgO}}
\end{aligned}
$$

Hyaloclastite volume will also be affected by porosity, which below $1 \mathrm{~km}$ depth $\left(\Phi_{d}\right)$ is taken to range from $0.08-0.12$ (ref. 66), and above $1 \mathrm{~km}\left(\Phi_{s}\right)$, where there is less compaction, from $0.12-0.3$ (refs 64,71 ). Given that the volcanic environment 
Carbonate cement $\left(\mathrm{kg} \mathrm{yr}^{-1}\right)$ : and regime will largely generate fine-grained glass particles, and considering the relatively high porosities and reactive surface areas, we consider an altered fraction $(P)$ ranging from 0.6-1.0, again typical of natural examples ${ }^{74}$. The resulting deposit is then subject to elemental losses (i.e., flux into the ocean and cement formation). For example, Ca losses $\left(L_{\mathrm{CaO}}\right)$ are assumed to range from $0.04-0.1$ of the altered fraction, as observed in natural samples ${ }^{72,73}$. These input distributions represent the main processes affecting annual variability in elemental flux.

A component of the elemental losses will form pore-filling cements and the remainder is assumed to go directly into the ocean. Cement fraction $\left(C_{C a O}\right)$ is highly variable in nature ${ }^{71}$. We therefore allow it to range from $0-1.0$ of the total amount of the leachate, and consider secondary phases that result in relatively high losses of elements. For calcium, we consider $\mathrm{CaCO}_{3}$ containing $\sim 56 \% \mathrm{CaO}$, while saponite clays (smectite) only contain $\sim 1.2 \% \mathrm{CaO}$. This approach leads to a conservative estimate of ocean flux, particularly as cement formation typically takes place over longer timescales $\left(>10^{5} \text { yrs }\right)^{74,75}$.

The model considers the formation of (i) carbonate fluorapatite (CFA) cement, with equation [5] giving the mass of $\mathrm{P}_{2} \mathrm{O}_{5}$ in cements, [6] the mass of $\mathrm{CaO}$ in cements, and [7] the total CFA cement mass; (ii) carbonate cement, with [8] giving the mass of $\mathrm{CaO}$ and [9] the total mass of $\mathrm{CaCO}_{3}$ cement; (iii) saponite clays, with [10] giving the total mass of $\mathrm{SiO}_{2}$ and [11] the total mass of saponite; and dolomite cement, with [12] giving the mass of $\mathrm{MgO}$ and [13] the total mass of $\mathrm{CaMg}\left(\mathrm{CO}_{3}\right)_{2}$ cement. In all cases the resulting mass released to the ocean is assumed to be $m^{o}=m-m^{c}$. The numbers of moles of $\mathrm{Ca}, \mathrm{P}, \mathrm{Si}$ and $\mathrm{Mg}$ released to the ocean are given in [14], [15], [16] and [17]. Equation [18] gives the equivalent fraction of hyaloclastite pore space filled with cement or clay.

Carbonate fluorapatite (CFA) $\left(\mathrm{kg} \mathrm{yr}^{-1}\right)$ :

$$
\begin{gathered}
m_{P 2 O 5}^{c}=C_{C F A} m_{P 2 O 5} \\
m_{C a O}^{c}=\left(\frac{0.56}{0.36}\right) m_{P 2 O 5}^{c} \\
m_{C F A}^{c}=\frac{100 m_{P 2 O 5}^{c}}{q_{P 2 O 5}}
\end{gathered}
$$

$$
m_{\mathrm{CaO}}^{c}=C_{\mathrm{CaO}} m_{\mathrm{CaO}}
$$




$$
m_{\mathrm{CaCO} 3}^{c}=m_{\mathrm{CaO}}^{c}+\left(w_{\mathrm{CO} 2}^{m o l}\left(\frac{m_{\mathrm{CaO}}^{c}}{w_{\mathrm{CaO}}^{m o l}}\right)\right)
$$

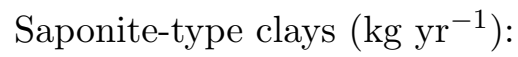

$$
\begin{gathered}
m_{\mathrm{SiO} 2}^{c}=C_{\mathrm{SiO} 2} m_{\mathrm{SiO} 2} \\
m_{\text {saponite }}^{c}=\frac{100 m_{\mathrm{SiO} 2}^{c}}{q_{\mathrm{SiO} 2}}
\end{gathered}
$$

645

Dolomite cements $\left(\mathrm{kg} \mathrm{yr}^{-1}\right)$ :

$$
\begin{gathered}
m_{M g O}^{c}=C_{M g O} m_{M g O} \\
m_{C a M g(C O 3) 2}^{c}=m_{M g O}^{c}+\left(2 w_{C O 2}^{m o l}+w_{C a O}^{m o l}\right)\left(\frac{m_{M g O}^{c}}{w_{M g O}^{m o l}}\right)
\end{gathered}
$$

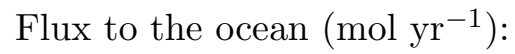

$$
\begin{gathered}
n_{C a}=m_{C a O}^{o}\left(\frac{1000}{w_{C a O}^{m o l}}\right) \\
n_{P}=2 m_{P 2 O 5}^{o}\left(\frac{1000}{w_{P 2 O 5}^{m o l}}\right) \\
n_{S i}=m_{S i O 2}^{o}\left(\frac{1000}{w_{S i O 2}^{m o l}}\right) \\
n_{M g}=m_{M g O}^{o}\left(\frac{1000}{w_{M g O}^{m o l}}\right)
\end{gathered}
$$

647 Pore fill:

$$
f_{f i l l}=\left(\frac{m^{c} / \rho_{\text {cement }}}{\left(\Phi_{s} v_{s}\right)+\left(\Phi_{d} v_{d}\right)}\right)
$$

648 Input parameter distributions are deliberately and conservatively wide to simulate 649 the full range of plausible conditions and high temporal and spatial variability during 
ridge formation. Ocean flux estimates for three variant scenarios, corresponding to (I) full unzipping with high hyaloclastite production, (II) full unzipping with moderate hyaloclastite production and (III) partial unzipping with moderate hyaloclastite production are presented to demonstrate model sensitivity to basic assumptions. Supplementary Information Table 2 presents the full range of input distributions for the full and variant scenarios.

Supplementary Information figure 3 shows the fluxes of (a) calcium and (b) phosphorus into the ocean as a function of spreading rate and accumulated deposit thickness (using full simulation values in Supplementary Information Table 2). Supplementary Information figure 4 shows estimated hyaloclastite volumes, and the effect of cementation on ocean flux of $\mathrm{P}$. The specific effect of cementation on the phosphorus flux was also considered (Supplementary Information Fig. 5), and shows that even cases involving high degrees of cement formation can still result in very high dissolved phosphorus fluxes (relative to the modern riverine flux) for long ridges. Supplementary Information figure 6 shows probability of exceedance for $\mathrm{Ca}$ and Si for the variant scenarios (I, II and III in Supplementary Information Table 2), alongside the full simulation.

A further simulation explores sensitivity to the temporal evolution of the rifting process, accounting for likely (but difficult to constrain) correlations between ridge length and magmatic productivity. Here we define three phases in the rifting process, based on the parameters used for the full simulation (observed global, present day averages): (A) Initiation, where ridge length is short $(\mathrm{R}=5000-10000 \mathrm{~km})$ but productivity is high $\left(\mathrm{S}=0.15-0.2 \mathrm{~m} \mathrm{yr}^{-1}, \mathrm{D}=1000-1500 \mathrm{~m}\right)$; (B) Mid-event $(\mathrm{R}$ $\left.=10000-15000 \mathrm{~km}, \mathrm{~S}=0.10-0.15 \mathrm{~m} \mathrm{yr}^{-1}, \mathrm{D}=600-1000 \mathrm{~m}\right)$; and $(\mathrm{C})$ Final stages of rifting where the ridge has reached its full extent but productivity is very low $\left(\mathrm{R}=15000-20000 \mathrm{~km}, \mathrm{~S}=0.05-0.10 \mathrm{~m} \mathrm{yr}^{-1}, \mathrm{D}=100-600 \mathrm{~m}\right)$. All other parameters are as defined in Supplementary Information Table 2 for the full simulation. Supplementary Information figure 7 shows the probability of exceedance for annual Ca flux for phases A, B and C, compared to the full simulation (shown in black). This shows that although we cannot explicitly model correlations between parameters (e.g. arising from temporal evolution), the full and variant scenarios provide a reasonable representation of cumulative fluxes over typical timescales associated with unzipping of Rodinia (order $10 \mathrm{Myr}$ ). Unfortunately, there is insufficient observational evidence to apply covariance estimates to other parameters used in our simulations. In the absence of robust evidence, any attempt to correlate parameters (for example, cement fraction and depth) would decrease the uncertainty, thereby reducing the spread of the output distributions and providing false certainty in the outputs.

To reconcile the results of the simulation with observed post-snowball cap carbonate and dolostone deposits, we estimate the thickness of precipitates that could form after 10 Myr accumulation of oceanic Ca and Mg (Figs 3c-d). Taking the simulated annual flux of $\mathrm{Ca}$ and $\mathrm{Mg}\left(\mathrm{mol} \mathrm{yr}^{-1}\right)$ as the average for the episode, and assuming a final deposition area equivalent to the modern day continental shelf $(A=2.8 \times$ $10^{13} \mathrm{~m}^{2}$ ) gives the following estimate for cumulative deposit thickness after $10 \mathrm{Myr}$ : 


$$
T=n^{m o l} \times 10^{7}\left(\frac{w^{m o l}}{1000}\right)\left(\frac{1}{\rho A}\right)
$$

where $\mathrm{n}^{\text {mol }}$ is the number of moles $\mathrm{yr}^{-1}$ from our simulation, $\mathrm{w}^{\text {mol }}$ is the molar weight of either carbonate, $\mathrm{CaCO}_{3}\left(100 \mathrm{~g} \mathrm{~mol}^{-1}\right)$ or dolomite, $\mathrm{CaMg}\left(\mathrm{CO}_{3}\right)_{2}(184.4$ $\mathrm{g} \mathrm{mol}^{-1}$ ), and $\rho$ is the density of the deposit, i.e. $\rho_{\mathrm{CaCO}}$ or $\rho_{\text {Dolo }}$ (Supplementary Information Table 4).

\section{Code availability}

We have opted not to make the computer code associated with this paper available because it is currently being developed for another follow-up study, but will be released when this work is published.

\section{Methods references}

(58) Pemstein, D., Quinn, K. M., and Martin, A. D. The Scythe Statistical Library: An Open Source C++ Library for Statistical Computation. Journal of Statistical Software 42, 1-26 (2011)

(59) Eyles, N. and Januszczak, N. 'Zipper-rift': a tectonic model for Neoproterozoic glaciations during the breakup of Rodinia after 750 Ma. Earth-Science Reviews 65, 1-73 (2004).

(60) Reid, I. and Jackson, H. R. Oceanic spreading rate and crustal thickness. Marine Geophysical Researches 5, 165-172 (1981).

(61) Wilson, D. S. Fastest known spreading on the Miocene Cocos-Pacific Plate Boundary. Geophysical Research Letters 23, 3003-3006 (1996).

(62) Storey, M., Duncan, R. A., and Tegner, C. Timing and duration of volcanism in the North Atlantic Igneous Province: Implications for geodynamics and links to the Iceland hotspot. Chemical Geology 241, 264-281 (2007).

(63) Torsvik, T. H., Smethurst, M. A., Meert, J. G., Van der Voo, R., McKerrow, W. S., Brasier, M. D., Sturt, B. A., and Walderhaug, H. J. Continental breakup and collision in the Neoproterozoic and Palaeozoic - A tale of Baltica and Laurentia. Earth-Science Reviews 40, 229-258 (1996).

(64) Alt, J. C. Subseafloor Processes in Mid-Ocean Ridge Hydrothermal Systems. In: Seafloor Hydrothermal Systems: Physical, Chemical, Biological, and Geological Interactions, Humphris, S. E., Zierenberg, R. A., Mullineaux, L. S., and Thomson, R. E., editors, 91, 85-114. American Geophysical Union (1995).

(65) Fisher, R. V. Submarine volcaniclastic rocks. Geological Society, London, Special Publications 16, 5-27 (1984). 
(66) Batiza, R. and White, J. D. L. Submarine lavas and hyaloclastite. In: Encyclopedia of Volcanoes, Sigurdsson, H., editor, 361-381. Academic Press, San Diego (2000).

(67) Planke, S., Symonds, P. A., Alvestad, E., and Skogseid, J. Seismic volcanostratigraphy of large-volume basaltic extrusive complexes on rifted margins. Journal of Geophysical Research 105, 19335-19351 (2000).

(68) Peate, I. U., Larsen, M., and Lesher, C. The transition from sedimentation to flood volcanism in the Kangerlussuaq Basin, East Greenland: basaltic pyroclastic volcanism during initial Palaeogene continental break-up. Journal of the Geological Society 160, 759-772 (2003).

(69) Bell, B. and Butcher, H. On the emplacement of sill complexes: evidence from the Faroe-Shetland Basin. Geological Society, London, Special Publications 197, 307-329 (2002).

(70) Jerram, D. A., Single, R. T., Hobbs, R. W., and Nelson, C. E. Understanding the offshore flood basalt sequence using onshore volcanic facies analogues: an example from the Faroe-Shetland basin. Geological Magazine 146, 353-367 (2009).

(71) Walton, A. W. and Schiffman, P. Alteration of hyaloclastites in the HSDP 2 Phase 1 Drill Core 1. Description and paragenesis. G3 4, 8709 (2009).

(72) Stroncik, N. A. and Schmincke, H. U. Palagonite - a review. International Journal of Earth Sciences 91, 680-697 (2002).

(73) Staudigel, H. and Hart, S. R. Alteration of basaltic glass: mechanisms and significance for the oceanic crust-sea water budget. Geochimica et Cosmochimica Acta 47, 337-350 (1983).

(74) Morton, A. C. and Keene, J. B. Paleogene pyroclastic volcanism in the southwest Rockall Plateau - Deep Sea Drilling Project Leg 81. In: DSDP Initial Reports, volume 81, chapter 19, 633-643. (1984).

(75) Desprairies, A., Bonnot-Courtois, C., Jehanno, C., Vernhet, S., and Joron, J. L. Mineralogy and geochemistry of alteration products in leg 81 basalts - Deep Sea Drilling Project (Rockall Plateau). In: DSDP Initial Reports, volume 81, chapter 28, 733-742. Ocean Drilling Program (1984). 
a ANS: ArabianNubian Shield EG: Eastern Ghats NC: Napier Complex

Laurentia magmatic province

b Eth: Ethiopia Mad: Madagascar
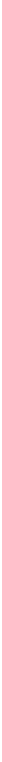

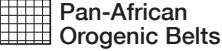

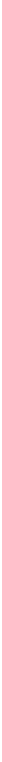

C

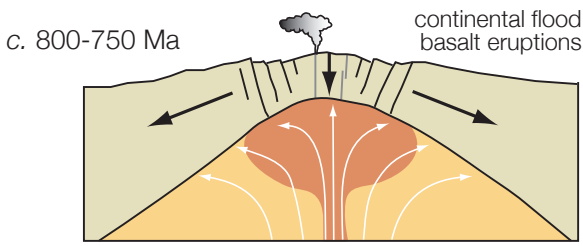

upwarping

c. $750-725 \mathrm{Ma}$ subsiding shallow submarine explosive eruptive phase (see d) water basin

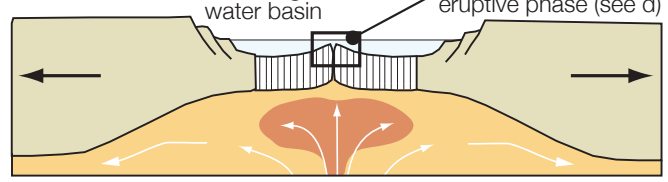

plate divergence
6

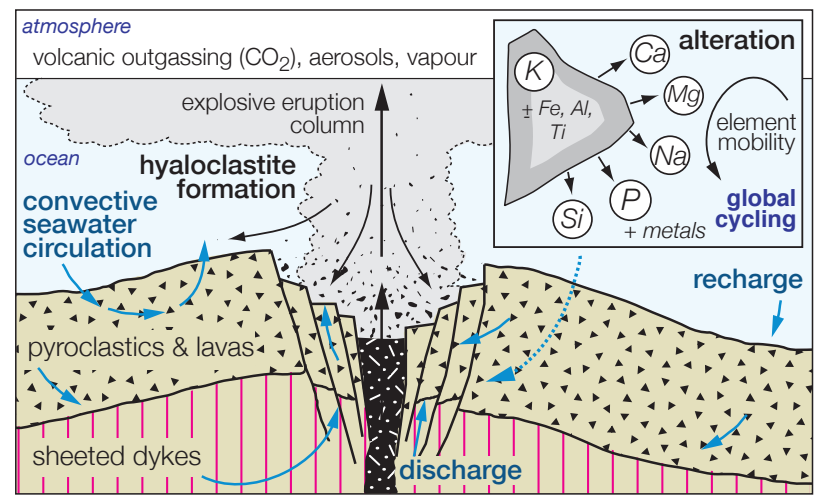


a

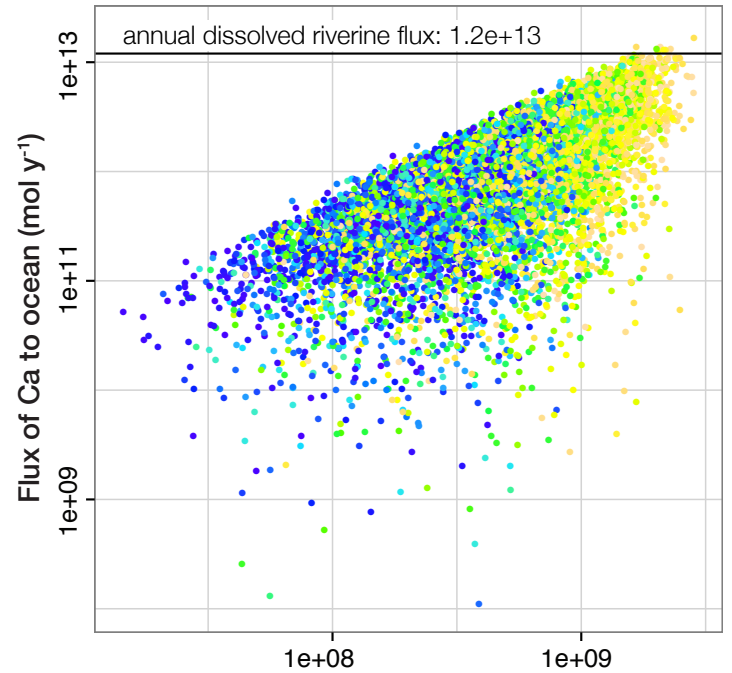

volume erupted hyaloclastite $\left(m^{3} y^{-1}\right)$

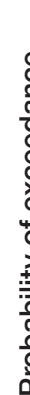

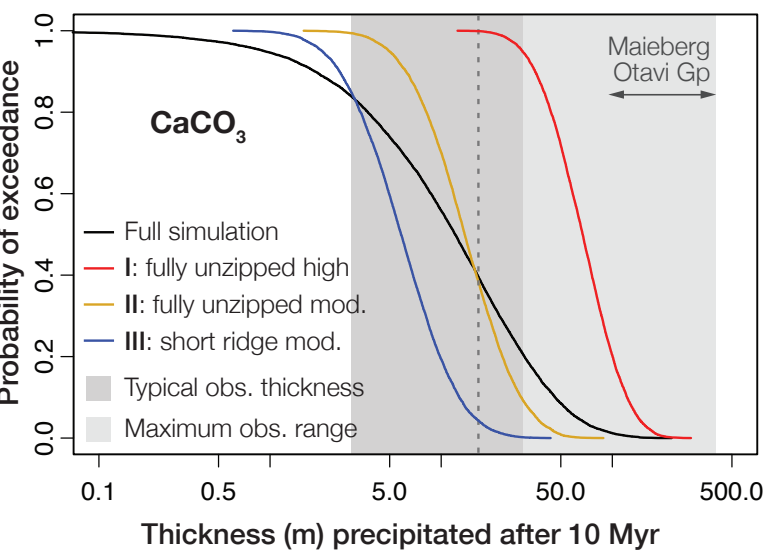

b
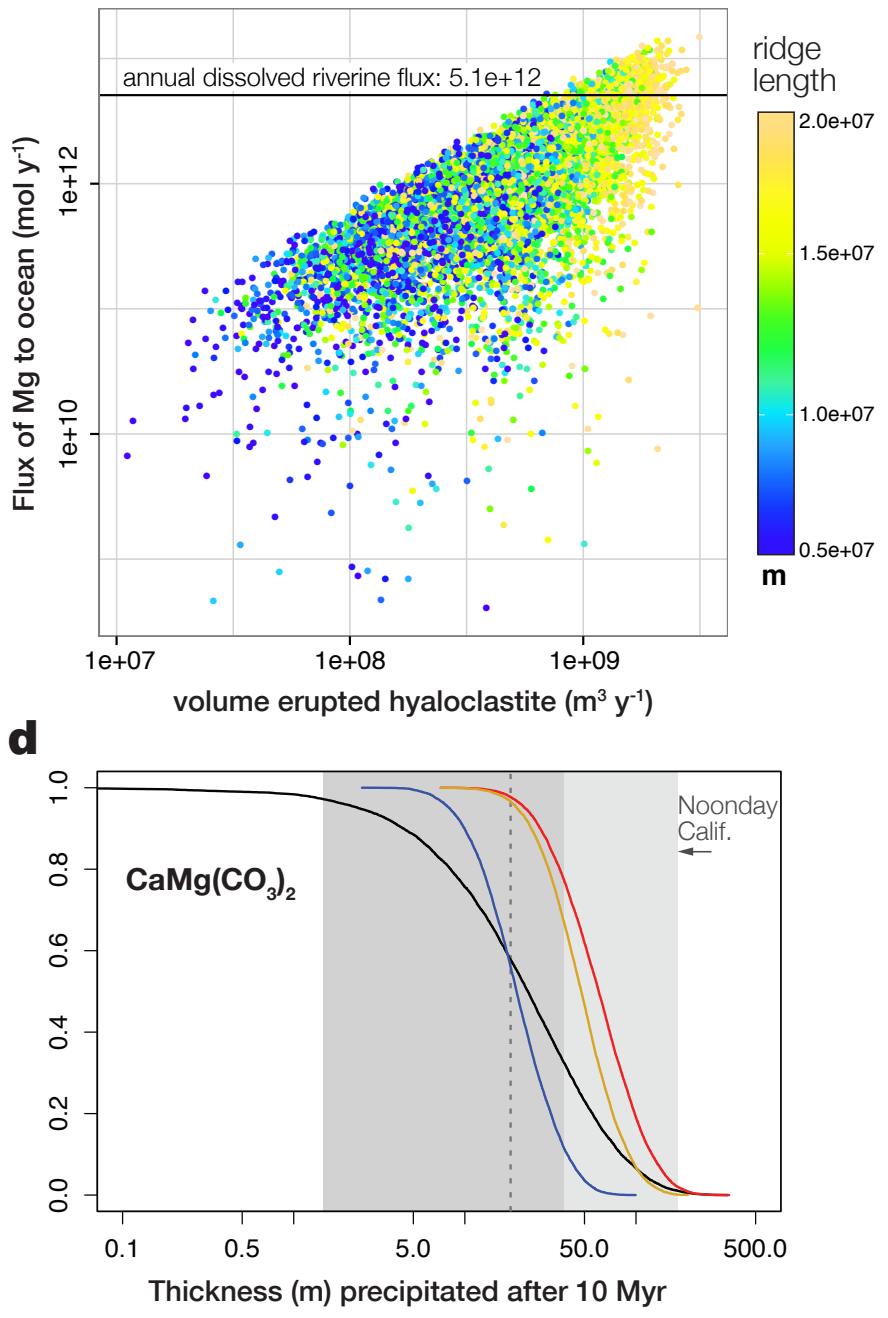


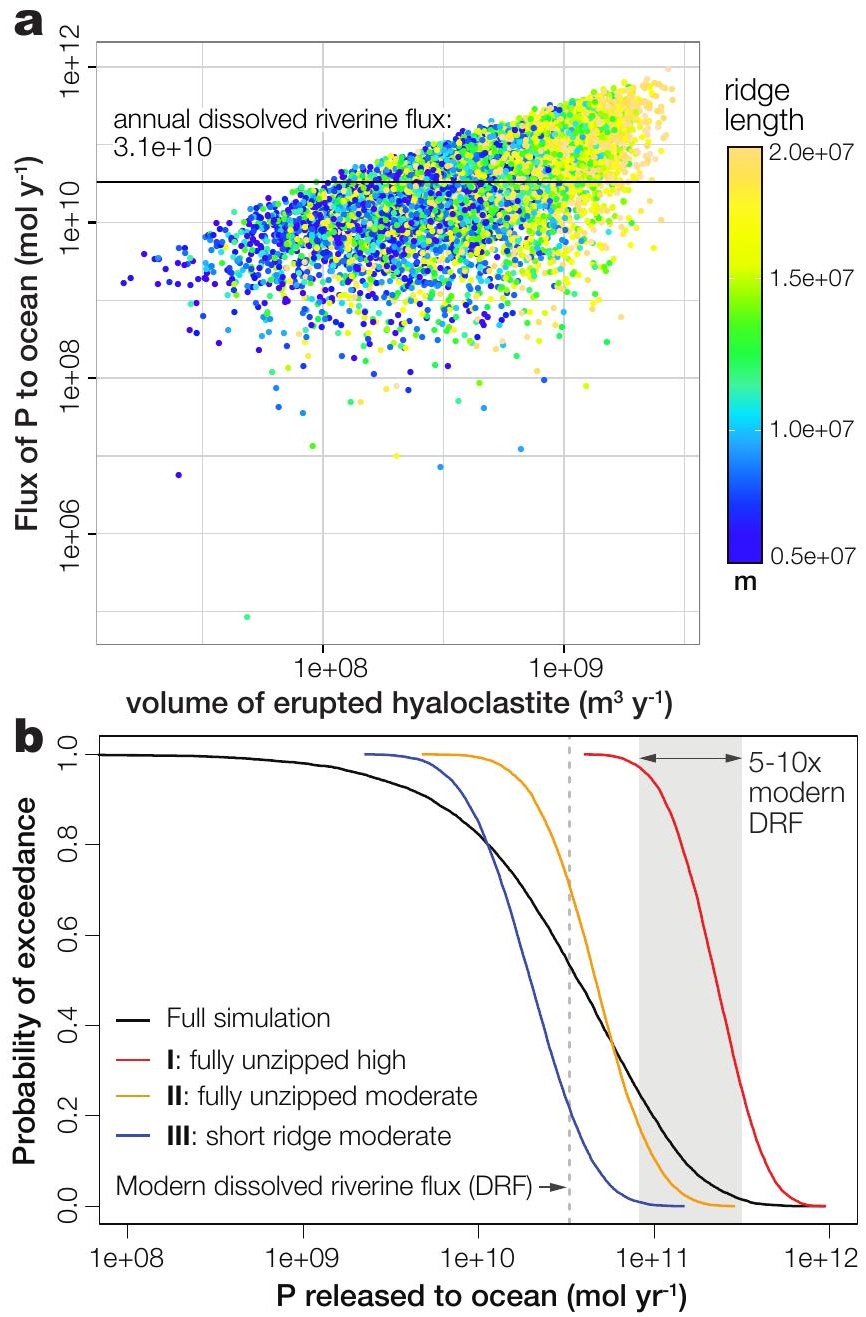

